\title{
Podnětná kniha ze Slovenska
}

\author{
Ivo Pospíšil (Brno)
}

Podoby ruského umenia 19. a 20. storočia. Klučové etapy vývoja ruského umenia 19. a 20. storočia a ich rezonancia v európskom kultúrnom priestore. Eds. Anton Eliáš - Michal Babiak. Bratislava: Katedra rusistiky a východoeurópskych štúdií Filozofickej fakulty, Univerzita Komenského, 2016. 308 s. ISBN 978-80-223-4038-0.

Bratislavští rusisté a estetici s filozofickými sklony se pustili do rozsáhlé práce na vylíčení podob ruského umění 19. a 20. století. Měli tu vedle sebe snahy podobné, zejména práce manželů Kupkových a Danuše Kšicové. ${ }^{1}$ Zde je však ambice obecnější, teoretičtější a současně slibuje i evropské přesahy. Práce to byla olbřímí a dopadla dobře: taková kniha je vždy užitečná i pro širší veřejnost, dobrá pomůcka pro studenty i jako úspěšný pokus o komplexní pohled na ruské moderní umění. Problémem je ovšem vždy vícečlenný autorský kolektiv: jinak to asi nejde, ale proto vzniká text rozrůzněný mentálně, metodologicky, strukturně, texty jsou různě komponovány, jsou heterogenní a hlavně jsou disperzní, rozbíhavé. Chtělo by to na závěr nějakou scelující studii, kde by se demonstrovalo sepětí různých druhů umění na ruské půdě a to, co se slibovalo, ale je př́ítomno jen stopově: světový význam ruského umění, ona transcendence, jež je zřejmá, zřetelná, ale zde málo využitá. Kniha je tedy souborem přehledů psaných $\mathrm{v}$ dobrém slova smyslu s vědeckou rutinou, někde i slovesně mimořádně kvalitně, jindy méně, více či méně nápaditě. Nemohu kompetentně posu-

1 Viz naše rec.: Ruská moderna (Zostavil Valerij Kupka. Bratislava: Slovart, 2011). Slavica litteraria, X 14, 2011, č. 2, s. 155-156; Ruská avantgarda (Zostavil Valerij Kupka. Bratislava: SLOVART, 2013). Proudy, 2016, č. 1; D. Kšicová: Od moderny $k$ avantgardě. Rusko-české paralely. Brno: Masarykova univerzita, 2007. http://www.phil. muni.cz/journal/proudy/filologie/recenze/2016/1/ pospisil_ruska_avantgarda.php\#articleBegin Slovnik ruskej umeleckej kultury 20. storočia (Valerij Kupka - Ivana Kupková: Slovnik ruskej umeleckej kultury 20. storočia. Prešov: Filozofická fakulta Prešovskej univerzity, 2014). Proudy, 2016, č. 1. http://www.phil.muni.cz/journal/ proudy/filologie/recenze/2016/1/pospisil_slovnil_ruskej_umeleckej_kultury_20_storocia.php\#articleBegin zovat partie o hudbě nebo filmu, méně rozumím divadlu, snad nejvíce literatuře. Zde bych vyzvedl zejména kvalitní části koeditora Antona Eliáše, jež se týkají ruské poezie a prózy 19. století, dobré jsou partie o 20. století, ostatní mohu posoudit jen rámcově: jsou to dobré přehledy, ovšem většinou bez kýžené transcendence.

V úvodu se autoři snaží ukázat na metodologická východiska a celkem zbytečně jdou „s kanónem na vrabce“, nebot spjatost těchto deklarací s vlastním textem je jen slabá, navíc s tím, že citovaná „moudra“ Svatoňova, Zajacova aj. se ocitají na hranici banality, jsouce spíše tautologiemi, věčnými pravdami, s nimž ani nikdo nepolemizuje, a tudíž ani nepředstavují žádné objevy ani metodologické posuny.

Jak již uvedeno, Eliášovy části jsou standardně kvalitní, jasně vyložené, s využitím autorových vlastních pohledů a nemělo by smyslu vracet se $\mathrm{k}$ detailům takového přehledového výkladu, jenž je invenční zvláště ve sféře poezie, jež je Eliášovou doménou. I když se tu a tam mihne nějaký zahraniční přesah, není to systémové. Výklad literatury 20. století patři k tomu lepšímu (Mária Kusá, Ivan Posokhin), i když zde také chybějí ony slibované přesahy, tedy „rezonancia“. Ta se kupodivu může týkat nejen ruské klasiky, moderny a avantgardy, ale také napřr. socialistického realismu (nehledě na to, že on sám je druhotně pramenem postmoderní travestie), který inspiroval světovou literaturu, takže zde vznikla díla i trvalejší hodnoty, ale také slabá na úrovni kýče. Na druhé straně sovětská inspirace vyvolávala i pokusy o jiné varianty; uved'me zde alespoň teoretické dílo Bedřicha Václavka a romány Vladislava Vančury nebo Marie Majerové z období první 
Československé republiky. Ruské dramatické umění je vyloženo kvalitně, nechybí tu ani partie o loutkovém divadle, což je velmi podnětné, nebot spojuje ruské umění s folklórem. Mimochodem ten je tu prrítomen jen stopově, ačkoliv byl velmi silným, jako u východních Slovanů vždy, inspirátorem moderního umění, nemluvě o staroruském umění a literatuře zvláště: tato návaznost zůstala ve svazku víceméně nevyužita. Myslím, že ne zcela exploatováno je tvarové specifikum ruského dramatu ve smyslu pojmu, který jsem razil jako zvláštnost ruské vývojové trajektorie - prae-post efekt: ten se projevuje u Gribojedova, Gogola, Ostrovského, jistě a především u Suchovo-Kobylina a Saltykova-Ščedrina, tvůrců groteskně absurdního dramatu dávno před jeho oficiální deklarací ve světě, jistě i u Čechova a jiných; méně pozornosti je věnováno tzv. sovětskému dramatu dvacátých a třicátých let 20. století. Možná se někteří autoři ocitli až př́liš $\mathrm{v}$ zajetí revizionistického trendu devadesátých let 20. století a šli v hodnotových posunech dost daleko: tak v literatuře má Fedin pouze jednu zmínka a Leonov zcela chybí: to se týká i některých představitelů jiných druhů umění. Výklad o filmu se týká jen užšího výseku. Samostatnou pozornost si zasluhuje exkurz Olivera Bakoše o filozofii a estetice, ale je tu málo propojenosti tzv. západních směrů s Ruskem, pouze úzce výběrově v podobě nevelkých zmínek, pominut je pozitivismus jako dominantní proud celého 19. a podstatné části 20. století, zejména v literární historii, stejně jako z něho (resp. z radikálního pozitivismu ruských revolučních demokratů) odvozovaný ruský marxismus, resp. krajní sociologismus, málo je tu Plechanov, chybí Lenin - již jen proto, že byli dobově recipováni, že se o nich diskutovalo, je třeba je zhodnotit a ukázat na souvislosti, fragmentární je tu ruská náboženská filozofie, chybí víc o euroazijství, více o sb. Věchi. Všeobecně tu pocituji rozpojenost výkladu západní a ruské filozofie. Např́klad je tu zmíněn Johann Joachim Winckelmann, ale jak v Rusku působil na umění se již nedovíme. Přitom právě tato kapitola mohla a měla být vskutku „parádní“, klíčová ve vztahu k předešlému výkladu s ohledem na kýženou scelující roli, jež ve svazku absentuje.

Bylo by možné věnovat se jednotlivostem, zejména těm, kde je recenzentova kompetence silnější, ale nebylo by to smysluplné vzhledem ke koncepci svazku a jeho polyfunkčnosti. Př́itomná kniha je reprezentativní ve smyslu představení slovenské rusistiky, filozofie/estetiky a uměnověd ve vztahu $\mathrm{k}$ ruskému fenoménu, nepochybně obecně zčásti zaceluje i zející mezeru v stávající odborné literatuře, její inovativní hodnota je však, jak jsem výše naznačil, nevyrovnaná a slibovaná „rezonance“ přece jen slabší, než se dalo očekávat, a to v obou směrech, tedy do Ruska i z Ruska. Pracovat na takovém projektu není nejlehčí a přináší vždy otázky metodologické, materiálové, koncepční i výkladové. Zkušení vědci se s tímto úkolem vyrovnali - nehledě na uvedené připomínky - se ctí; svazek má svou poznávací hodnotu a jeho čtivost, která je ovšem kolísavá, umožní plnit nejen vědeckou, ale i obecně osvětovou funkci.

E-mail:ivo.pospisil@phil.muni.cz 